\title{
A VISÃo MELANCÓLICA COMO POLÍTICA DA REDENÇÃo
}

\author{
Rodrigo Rocha Rezende de Oliveira
}

\begin{abstract}
RESUMO
Este artigo está organizado em três tempos nos quais primeiro introduzimos o temário da melancolia a partir de sua imanência política no contexto social implicado na obra de Walter Benjamin (1892-1940). Em um segundo momento, buscamos conceituar a intenção melancólica (do olhar) como princípio de uma política da redenção. E, por fim, trazemos à tona uma noção de "redenção às avessas" que se apoia justamente nesta intenção melancólica localizada finalmente na teoria da linguagem benjaminiana. Sobretudo, buscamos o radical da redenção por via desta intenção melancólica sem nos deixar levar por uma ideia da melancolia enquanto esmorecimento, ou, apenas tristeza. Essa, talvez seja a virada que viemos propor, indo ao largo de qualquer concepção da melancolia que esteja afastada de sua vinculação social intrínseca, e sua incorporação a posteriori por Benjamin, no exercício de escrita de suas reflexões sobre a modernidade. Propomos ao leitor uma incursão sobre o radical do conceito de melancolia desde as reflexões que Benjamin faz em "Origem do Drama barroco Alemão" para daí podermos acessar suas implicações na política da escrita que o filósofo retoma posteriormente. Também a expressão alegórica será abordada, então, desde esta mesma intencionalidade melancólica que aparece deflagrada no percurso que traçamos ao longo de nosso texto.
\end{abstract}

Palavras-chave: Alegoria. Melancolia. Política. Redenção. Revolução.

\section{THE MELANCHOLIC VISION AS A POLICY OF REDEMPTION}

\begin{abstract}
This article in three times organized, in which we first introduce the theme of melancholy from the political immanence in the social context involved in Walter Benjamin's work (1892-1940). Secondly, we seek to conceptualize the melancholic intent as a principle of a policy of redemption and, finally, we bring a notion of "backwards redemption" which is based on this notion of a melancholic intent. Above all, we seek the radical of redemption through the melancholic intention without, however, letting ourselves weakened be away by an idea of melancholy as a weakening. Perhaps, is the turning point that we have come to propose; going beyond any conception of melancholy that is far from is intrinsic social bond, and its incorporation a posteriori by Benjamin, in the exercise of writing his reflections on modernity. Finally, we propose to reader an incursion into the radical concept of melancholy from Benjamin's reflections in "The Origin of a German Tragic Drama" so that we can access its implications in the politics


of Benjamin writing. The allegorical expression will also be addressed then, form this melancholy intentionality triggered in the course of the text.

Keywords: Allegory. Melancholy. Policy. Redemption. Revolution.

\section{Introdução: 0 "índice secreto" da redenção se encontra no passado dos oprimidos}

É curioso o esforço crítico que realiza Enzo Traverso (2018), no livro "Melancolia de Esquerda: Marxismo, História e Memória", ao falar sobre a profunda amizade entre Benjamin e o filósofo alemão Theodor W. Adorno (19031969). Em um dos tópicos para determinada seção interna do livro, intitulada Adorno e Benjamin: Cartas na meia noite do século, Traverso (2018) explora algumas "Hierarquias" - palavra que representa o subtítulo de tal seção - na relação entre os dois amigos.

Ao escrever sobre a desigualdade econômica nas condições sociais entre as vidas de Benjamin e Adorno desde os anos de 1930, Traverso (2018) sugere uma clara sujeição material do primeiro em relação ao segundo. ${ }^{1}$ Acontece que, nos idos de 1930, Benjamin teria dedicado ao meio literário na Alemanha da República de Weimar, o tempo e o serviço, que o jovem promissor Adorno, nem sequer poderia imaginar. Mas, essa constatação não representaria nada quanto ao sucesso profissional de ambos os intelectuais.

Como escreve Traverso: "Ciente de ser um mediador indispensável [Adorno para Benjamin] entre seu amigo exilado e a Escola de Frankfurt, [aquele primeiro] adotou conscientemente uma postura que ia muito além de um crítico

\footnotetext{
${ }^{1}$ Neste mesmo trecho do texto Traverso faz a seguinte consideração que também gostaríamos de ressaltar: "Tal distância entre os dois - progressivamente reduzida, porém nunca eliminada por completo - [Isso após falar sobre o tom formal que Adorno e Benjamin praticavam mesmo na sua relação interpessoal] também se encontra em um aspecto paradoxal da relação deles: após 1933, Adorno, ainda jovem, "o recipiente", logo atingiu uma posição dominante, de um ponto de vista material e "institucional". O trabalho de Benjamin foi desenvolvido nos anos de $1920 \mathrm{e}$ 1930, desde seu livro Origem do drama trágico alemão ao aforístico Rua de mão única, de seu artigo seminal sobre a cultura de massa a "Teses sobre o conceito de história", de seus artigos literários a seu livro inacabado sobre a Paris do século XIX. Na época, o trabalho de Adorno mal começava a tomar forma. Ele acabaria publicando seus principais livros somente nos anos pósguerra." (TRAVERSO, 2018, 382).
}

Mestrando em Filosofia pela Universidade Federal de Ouro Preto. Brasileiro, residente em Juiz de Fora - MG. Email: rodrigorochadeoliveiracod@gmail.com 
fraternal: ele se tornou um patrono, (...) e mais detestável ainda, um censor."2 (TRAVERSO, 2018, 383).

Descrição que Traverso (2018) complementa ao anotar, sob minúcias, a total dificuldade para sobrevivência enfrentada por Benjamin: “(...) a partir de 1937 ele [Benjamin] começou a receber todo mês escassos oitenta dólares do Instituto de Pesquisa Social (...), uma quantia que passou a ser imprescindível para sua sobrevivência, em termos materiais e psicológicos" (2018, 386). Afinal, por se tratar de um pensador irreverente e antenado como Benjamin, podemos imaginar que quaisquer barreiras meramente ideológicas ao seu trabalho seriam demasiado lamuriantes.

No relato que concede Hannah Arendt (1906-1975), a falar sobre este período - descrito oportunamente por Traverso - , constatamos que ela: "Hannah Arendt, que costumava fazer visitas regulares a Benjamin em Paris durante seus anos de exílio, testemunhou sua ansiedade [a ansiedade de Benjamin] ao confrontar permanentemente a espada de Demócles do instituto." $(2018,387)$. Não somente por isso, todavia, como sabemos, Benjamin veio a se decidir sobre o perjúrio deste limitado estado ao tomar para si aquela escolha de insubmissão absoluta que tomara Sócrates.

Por fim, Traverso (2018) arrisca uma hipótese para o significado heroico do suicídio de Benjamin em que, apesar dos pesares, dispõe das seguintes palavras "redentoras" como o fim deste percurso: "Seu suicídio foi ato de desespero, assim como um testemunho contra o fascismo, quando toda $e$ qualquer chance de escapar parecia perdida." (TRAVERSO, 2018, 394-395, grifo nosso)..$^{3}$

\footnotetext{
2 Variantes que nos interessa também porque, estas são as condições econômicas de Benjamin desde a morte do pai, seu principal mantenedor até os anos de 1926 - ano da morte do pai de Benjamin (TRAVERSO, 2018). Traverso elabora uma versão minuciosa sobre a rede "donativa" que Benjamin forjou nas épocas mais difíceis, desde os anos de 1933. Como escreve Traverso, enfim, nos tempos de exílio: "De 1933 em diante, [Benjamin] viveu em Paris como exilado, em condições miseráveis, dependendo das esporádicas ajudas das instituições judias, como a Alliance Israélite Universelle, e do auxílio de alguns amigos." $(2018,285)$ Ou seja, cada nuance intencional que Benjamin dirige ao mundo de sua experiência histórica, como sabemos, será conduzido pela melancolia que, de certa forma, é performática na práxis do seu engajamento crítico literário. Sua reflexão imersa nas memórias de um passado necessariamente preterido e pelo qual o sujeito intervém na mobilização da tradição dos oprimidos, faz seu modo de apanhar as coisas um modo melancólico por excelência.

${ }^{3}$ Traverso descreve o conhecido cenário dos dias finais na vida de Benjamin por uma figuração muito própria e expressiva, ao que viemos destacar, ainda, a seguinte passagem que assumimos para nossa reflexão em que também as perspectivas futuras de Benjamin eram fatais e não Mestrando em Filosofia pela Universidade Federal de Ouro Preto. Brasileiro, residente em Juiz de Fora - MG. Email: rodrigorochadeoliveiracod@gmail.com
} 
Neste ensaio, viemos rastrear o significado do sacrifício no interior da teoria da linguagem benjaminiana - isso após mencionarmos o sacrifício enquanto absurdo concretizado no próprio corpo cristão, como flagelo da carne pecaminosa. Sobretudo, enxergamos o sacrifício pressuposto por uma visão melancólica no exercício de sua política redentora. Essa perspectiva sobre o mundo que terá, no conceito de juízo, a efetivação para o ato abrupto de dar sentido ao mundo durante o evento da queda adâmica de uma linguagem que é a possibilidade de salvação.

Este olhar melancólico-redentor fixado no interior da fragmentação do mundo e que toma a figuração da salvação que imagina para os fenômenos e as ideias conforme uma narrativa que contenha no seu registro memorial o cordão linguístico que fora maculado pelo ajuizamento. Permitido, enfim, por uma intencionalidade política - expressão encontrada nas letras e nas escolhas narrativas que incorre o historiador materialista heterodoxo - e que seleciona seus objetos como algo implicado nesta mesma intenção melancólica, a qual viemos buscar expor neste trabalho. ${ }^{4}$

Em nosso roteiro, destacamos, primeiramente, que a história revolucionária, como pensada de forma crítica por Benjamin, se apresenta sob

somente sua agonia final: "Ele se matou em Portbou, após ter sido preso na fronteira com a Espanha e ameaçado de ser entregue às autoridades francesas (e consequentemente à Gestapo). Seus companheiros de travessia acabaram cruzando a fronteira até alcançar Lisboa, de onde embarcaram para Nova York. Não só lhe faltou energia para tal viagem como preocupava a vida em Nova York, onde ele tinha medo de acabar se tornando uma peça de museu, "o ultimo europeu." [Passagem, portanto, em que Traverso faz citação à Arendt, e assim levanta a hipótese que tanto nos chamou atenção na sua abordagem para o acontecimento do suicídio de Benjamin]". (TRAVERSO, 2018, 394-395).

${ }^{4} \mathrm{O}$ aparecimento simultâneo de uma nuvem conceitual única, neste momento, que sobrevoa, então, o território comum na obra de Benjamin, precisa ser evocado tendo em vista sua filiação marxista, desde a metade da década de 1920. Além disso, o liame proposicional nos conceitos de memória e história, que vagam sobre o mesmo espaço com que vagam melancolia e conhecimento, mobilizam declives alternados entre si. Dizemos isto porque da mesma maneira que a memória e a história guardam uma proporcionalidade mediada pela genuína memória afetada pela tradição dos oprimidos, sobrepor a cientificidade impingida à historiografia desde a facticidade alocada no pensamento historicista, também é algo revisto aqui. De maneira que, a intenção melancólica por uma operação diferente, porém, plasticamente afetada, faz desta, uma sobreposição ao conhecimento abstracionista no cientificismo pregado pela ortodoxia marxista, por exemplo. Por outro lado, a memória declina à uma visão melancólica sobre a história, quando não, uma historiografia árida e positivista, forjaria o conhecimento do objeto factual como verdade para retratar suas vitórias. Enfim, passamos a nos atentar, a partir disso, com essas tensões conceituais muito presentes nas discussões levantadas.

Mestrando em Filosofia pela Universidade Federal de Ouro Preto. Brasileiro, residente em Juiz de Fora - MG. Email: rodrigorochadeoliveiracod@gmail.com 
a roupagem de uma peculiar doutrina da tradição dos oprimidos. Uma tradição que reclama pela redenção dos antepassados transformada em energia capital para os embates na luta presente e que soergue como seu elenco todos os detritos excluídos pela narração hegemônica.

Como escreve Traverso: "A história se agarra à memória dos derrotados, às lembranças das derrotas sofridas e à promessa de redenção futura." (TRAVERSO, 2018, 420). Ou ainda, se pensamos uma "redenção" que permanece por vir, desde o escopo da teoria da linguagem benjaminiana, a rememoração dos excluídos, confere ao conhecimento redentor o atributo da transmissão melancólica.

O passado dos oprimidos, no plano de incursão na realidade por via desta intenção errante, no mundo das significações taciturnas - sempre ansiosa pela morte e ainda não redimida —, mostra porque a noção da memória será melancólica, enquanto a de história, a princípio, uma noção estreita e razoavelmente progressista.

Quando Benjamin escreve na "tese" de número II do espólio Sobre o conceito de história: "O passado leva consigo um índice secreto pelo qual ele é remetido à redenção. Não nos afaga, pois, levemente um sopro de ar que envolveu os que nos precederam?" (BENJAMIN, 2005, 48), entrevemos justamente este espírito como fundamento para esta indagação levantada pelo autor.

Por outro lado, um tipo observador historicista estranharia esse modo de "olhar político" sobre o passado - como Benjamin escreve no ensaio sobre o surrealismo, de 1929 - porque o passado se mostra plenamente naturalizado a seu ver. Os fatos são suficientes em si mesmos e não há o que desvendar por força da redenção, porque, o espectro de seu passado está condecorado com todos os louros da vitória.

Benjamin escreve na "tese" de número $\mathrm{V}$ - no polo negativo da menção anterior, para os historicistas, o que arregimenta seu olhar será o fato consumado e a certeza de que: "A verdade não nos escapará - essa frase de Gottfried Keller indica, na imagem que o Historicismo faz da história, exatamente o ponto em que ela é batida em brecha pelo materialismo histórico." (BENJAMIN, $2005,62)$. Os escombros que o observador melancólico exume, fazendo dos 
destroços a figura emblemática das alegorias, o olhar ligado ao historicismo, por exemplo, simplesmente descartaria, de acordo com sua intenção positiva sobre os acontecimentos.

Marcelo de Mello Rangel, no ensaio "Melancolia e história em Walter Benjamin", publicado em 2016, se ocupa do modo afetivo com que a melancolia se espraia pela narrativa histórica pensada a partir de Benjamin. No seu texto, Rangel (2016) descreve as figuras benjaminianas na "tese" de número II, a fim de enfatizar a remoção dos sentidos que devêm, pode-se dizer, a uma fortuna da "memória dos oprimidos", também como virtude assimilada no "tempo de agora" (Jeztz-Zeit).

Sobretudo, determinada noção de "possibilidade" - amplamente explorada por Rangel (2016) — de estruturas sensíveis perdidas no passado, pelo crivo da narrativa revolucionária, emergirem socialmente, digamos, engajadas, nos afeta diretamente: "Estes conjuntos de sentidos ou mesmo realidades obscurecidas [que] se oferecem ao presente, na forma de 'um encontro secreto` (...)." (RANGEL, 2016, 131).

Motivo pelo qual Rangel acrescenta uma margem decisiva para termos em conta uma abertura radical da história: "Neste sentido acrescentaríamos que ocorre a partir deste 'encontro secreto 'que a história abre-se à atualização de seu caráter de possibilidade, ou seja, temos as condições ideais para que determinado conjunto de sentidos protagonista ou certa realidade imediata possa ser contestada e deslocada. (RANGEL, 2016, 131).

Enquanto instrumento de combate, 1) a memória alegórica desloca os sentidos revolucionários para uma "epifania" redentora, consumada na significação metafórica e no milagre da palavra emancipatória. Consonante a isso, os novos sentidos produzidos, oriundos da memória da opressão, organizam ações diretas no seu jubiloso momento de salvação tendo em vista este plano inicial, especulativo e imerso na linguagem.

Por outro lado, 2) a memória como imaginação crítica, muito por força da intenção melancólica - como também nos fala Rangel (2016) —, também reorganiza seus objetos de modo eminentemente político. Ao tratar como centrais os artefatos antiquados, os elegendo em prol do "enfrentamento de determinada realidade sedimentada ou imediata", o pensamento benjaminiano e Mestrando em Filosofia pela Universidade Federal de Ouro Preto. Brasileiro, residente em Juiz de Fora - MG. Email: rodrigorochadeoliveiracod@gmail.com 
sua reflexão sobre a cultura suscita uma memória particular do sofrimento e de uma tradição dos oprimidos.

Raymond Williams (2011), no livro intitulado "Política do Modernismo", descreve tipos de atitudes engajadas e direcionamentos plurais que perpassam a luta ideológico-política vincada no campo cultural da modernidade. ${ }^{5}$ Poderíamos dizer que, suas nuances, variantes e desdobramentos inesperados, são expectativas também experimentadas radicalmente por Benjamin.

Contextualmente, enxergamos que há um sem-número de indícios nesta elaboração que nos ajudam a pensar uma proximidade destas correntes com o pensamento de Benjamin. Williams sugere uma aplicação didática em torno da teoria sobre a vanguarda lançando mão do desdobramento central entre uma concepção de vanguarda e a própria concepção de modernidade artística, que nos serve como base comparativa.

O autor elabora esta diferença ao escrever o seguinte sobre as vanguardas: "(...) esses agrupamentos [os agrupamentos das vanguardas] se desenvolveram em formações totalmente oposicionais, determinadas a promover suas próprias obras, mas a atacar seus inimigos nas instituições culturais e, além disso, a atacar toda a ordem social." (WILLIAMS, 2011, 30).

Ora, se pensarmos a obra de Benjamin neste mesmo âmbito - inclusive completamente inserida nas transformações sociais e culturais do período, desde 1920 a meados de 1940 —, a vertente da crítica polêmica, a que Benjamin identifica o escritor Karl Kraus isso seria um termo fundante para sua crítica.

\footnotetext{
${ }^{5}$ Nas palavras de Raymond Williams este quadro poderá ser fixado no seguinte modelo: "Podemos distinguir três fases que se desenvolveram rapidamente durante o final do século XIX [Justamente fases na história das vanguardas modernas]. Inicialmente houve grupos inovadores que procuravam proteger sua atividade artística dentro de uma dominação crescente do mercado das artes e contra a indiferença das academias formais. Numa segundo fase, esses grupos se desenvolveram em agrupamentos inovadores alternativos e mais radicais, procurando prover seus próprios meios de produção, de distribuição e de publicidade. Finalmente, esses agrupamentos se desenvolveram em formações totalmente oposicionais, determinadas a promover suas próprias obras, mas a atacar seus inimigos nas instituições culturais e, além disso, a atacar toda a ordem social na qual esses inimigos haviam ganhado poder, agora 0 exercendo e reproduzindo-o. Então, a defesa desse tipo particular de arte tornou-se, primeiramente, uma autogestão de um novo tipo de arte e, de forma decisiva, um ataque, em nome dessa arte, a toda uma ordem social e cultural." (WILLIAMS, 2011, 30, grifo nosso).
}

Mestrando em Filosofia pela Universidade Federal de Ouro Preto. Brasileiro, residente em Juiz de Fora - MG. Email: rodrigorochadeoliveiracod@gmail.com 
Assim como veremos adiante, uma "crítica polêmica", de acordo com o que o próprio Benjamin (2018) irá defender, pressupõe uma fermentação política para que possa ser concretizada. Isto é, semelhante ao caráter "oposicional", como nas palavras de Williams, a crítica polêmica toma o primor da linguagem atrelada àquela agonia (sócio e cultural), da qual falávamos, como o encargo de seu leit motiv.

Para agudizarmos esta investigação, para tomarmos a noção deste contraste entre as noções de vanguarda e modernidade sublinhamos que Williams afirma o seguinte: "A vanguarda, agressiva desde o início, via-se como a desbravadora do futuro: seus membros já não eram os portadores do progresso já repetidamente definido, mas os militantes de uma criatividade que reviveria e libertaria a humanidade."6 (WILLIAMS, 2011, 30).

Uma ressalva - pautada sobre o aspecto na crença do progresso, sublinhada então por Williams (2011) —, preciosa que arregimenta nossa leitura primeiro porque Benjamin jamais se ligaria a uma concepção do progresso como descrita antes. Além do mais, Williams aponta para outros três fatores nesta concepção sobre a vanguarda, que nos ajudam a pensar suas relações com a obra e o pensamento de Benjamin, a saber: a revalidação da criatividade; a negação da tradição, na contrapartida do primeiro termo proposto; e, por último, o espírito antiburguês (WILLIAMS, 2011).

A crítica direcionada ao progresso, que Benjamin eleva como irrevogável nas "Teses", está presente teoricamente no seu pensamento na mesma medida que uma crítica geral da burguesia, sintonizadas por seu anticapitalismo e antimercantilismo. Isto porque são os burgueses que representam a camada da sociedade moderna mais arraigada naquele modelo comercial vigente e desenvolvida a partir de uma simbologia capitalista.

Preterida pelo aristocrata, que a enxerga como arguta e fugaz, e detestável para os operários, que viam nos burgueses nada menos do que os

\footnotetext{
${ }^{6} \mathrm{O}$ trecho é ao mesmo tempo revelador de uma proximidade incontestável no sentido de uma margem para as ideologias do progresso, modo geral, mas, como devemos sublinhar, Benjamin não se identifica com a mesma visão sobre o futuro. Pelo contrário, Benjamin, sobretudo, nas "Teses" permanece um aficionado pelo passado como desvio para a própria redenção. Porém, achamos válido tomar o revés desse paradoxo como exemplo para nossa introdução ao levarmos em consideração determinado espírito que não poderia ser negligenciado pelo pensamento benjaminiano no seu contato social incontornável com o surgimento das vanguardas.
} 
detentores dos meios de produção que os submetiam a exploração. Uma classe que aparece, portanto, atravessada transversalmente não somente por uma crítica radical provinda das diferentes camadas antagonistas como pelos próprios intelectuais marginalizados.

Como escreve Williams: "Nenhuma questão é mais importante para nosso entendimento desses movimentos [Quer dizer, os movimentos da vanguarda artística moderna, ao qual reaproximamos o pensamento de Benjamin], em sua época, modernos do que a ambiguidade do 'burguês'. A ambiguidade subjacente é histórica, em sua dependência da posição de classe variável a partir da qual o burguês era visto." (WILLIAMS, 2011, 34).

Diga-se de passagem, o título dado para essa classe como "mediana", no sentido de escassez, está em voga para toda crítica benjaminiana da sociedade. Bem como, o lugar social ocupado Benjamin, como intelectual ultrajado pelos estigmas étnicos e políticos, que o posicionam enquanto resistência a esta mesma classe burguesa cumpre papel próximo daquele assumido pelos operários, mas demonstra seu antagonismo particular.

Todavia, o entendimento da tradição será uma exceção, entre os termos supracitados desde a leitura de Williams (2011), que poderiam nos servir para uma abordagem afinada com o pensamento de Benjamin. Ou seja, o limite de nossa leitura comparativa deve situar, antes de qualquer coisa, a interpretação benjaminiana da tradição, que extrapola o cientificismo moderno de uma maneira eclíptica.

O espaço lacunar em que, no cenário barroco das significações se reflete determinada figura do abismo, configura uma espécie de redução sui generis na metodologia de Benjamin dirigida para esta abordagem apropriada por ele. Se as vanguardas tinham, no seu ímpeto progressista, uma tendência para o abandono das tradições - segundo Williams (2011), até mesmo em prol de uma suposta revalidação absoluta da criatividade -, Benjamin (2005), por seu turno, se coloca na linha de frente de uma tradição outra que é a tradição dos oprimidos.

Sob os reclames da memória revolucionária, pela construção de uma narrativa histórica dolente e fiel ao sangue dos antepassados, Benjamin contraria olhares comuns. A filosofia de Benjamin interrompe o fluxo do tempo vazio em Mestrando em Filosofia pela Universidade Federal de Ouro Preto. Brasileiro, residente em Juiz de Fora - MG. Email: rodrigorochadeoliveiracod@gmail.com 
que transcorre o progresso - pretensamente sempre avante e indiferente aos seus excessos - conforme seria apropriado a esta ideologia vanguardista assumir.

Tal concepção benjaminiana, para uma tradição dos oprimidos, permanece afirmada naquela intensidade conceitual de uma experiência transmitida através das gerações, ao se tornar o arcabouço de um conhecimento construído no tempo histórico e transmitido através das gerações. Mesmo a inventiva vanguardista, contrária à ideologia burguesa, que Benjamin observa criticamente tudo tem a ver com este problema da tradição, porque o grau de ineditismo na visão vanguardista anseia perpetuar uma novidade realmente extraordinária.

Como escreve Williams: “(...) era a massa que o artista criativo deveria ignorar ou se esquivar, ou a qual cada vez mais deveria chocar, ridicularizar e atacar." (WILLIAMS, 2011, 34). Porém, seu trajeto hiperbólico para a superação dos limites impostos à expressividade artística, engendrou, como fosse um rebote perverso, outro limite ainda mais ajustado que este das formas estéticas, e que acabou influenciando a política das vanguardas o mais definitivamente.

Talvez, o salto benjaminiano na interpretação marxista da história e da revolução culmina numa necessária evocação messiânica das lutas inglórias enquanto conteúdo histórico fundamental ao se deslocar criticamente acerca do pensamento provindo das diferentes fontes culturais modernas.

A criatividade, como axioma basilar das vanguardas, uma vez retida enquanto criação aleatória de quaisquer aquisições intermediárias provenientes da tradição, também escaparia de uma afinidade com a política benjaminiana de crítica a ideologia moderna do progresso.

Pelo contrário, a criatividade, como Benjamin (2013) sugere, por exemplo, no livro sobre a "Origem do drama barroco alemão", em relação ao caractere eruptivo das alegoreses, pressuporia o acordo técnico indissociável à sua expressão além de recobrar laços com a tradição que se tornam inalienáveis. ${ }^{7}$

\footnotetext{
${ }^{7}$ Sobre o problema da criatividade, pensada desde sua interdependência social, principalmente, para o caso das vanguardas e por extensão para obra de Benjamin, Raymond Williams escreve o seguinte: "No século XIX, o elemento proveniente da crítica aristocrática era, obviamente, muito mais forte, mas encontrou uma forma metafórica própria que sobreviveria, pateticamente, até 0 século XX [Justamente ao falar sobre a crítica da classe burguesa e seu modo de vida], para ser mesmo tomada por pessoas das quais isso não seria esperado: a defesa, na verdade, a Mestrando em Filosofia pela Universidade Federal de Ouro Preto. Brasileiro, residente em Juiz de Fora - MG. Email: rodrigorochadeoliveiracod@gmail.com
} 
De acordo com Williams (2011), o deslocamento desse espírito criativo para um refúgio aristocrata, contrário ao aburguesamento tendencioso do mundo capitalista, nos levaria ao cabo de uma iniciativa crítica sobre a própria massificação. ${ }^{8}$ Seus desdobramentos são multiplicados na mesma velocidade que estas classes se transformam dentro da sociedade moderna e na sua órbita estão os mais distintos personagens históricos, com todas as suas contradições pertinentes permanecidas em aberto.

Ainda na sequência do argumento, Williams discorre sobre a total contingência da própria crítica destinada a burguesia que é registrada então no alvorecer dos novos tempos: "Logo, dentro do que podem parecer, num primeiro momento, denúncias bastante similares à burguesia, há posições radicalmente diferentes que conduziriam, por fim, tanto na teoria quanto sob a pressão da crise política real." (WILLIAMS, 2011, 36).

Enfim, será esse o nosso parâmetro interpretativo, por exemplo, na abordagem do texto em que Benjamin critica a "Nova Objetividade" na Alemanha do pós-expressionismo, porque o espectro do encanto com o Surrealismo, na França, também estipula um dado contextual.

Na sua descrição Williams (2011) busca mostrar como os surrealistas também como leitura ordinária de Benjamin - estariam à frente de uma alternativa contrária ao belicismo, por exemplo, e afinados ao motim revolucionário perpetuado na transformação cultural. E o próprio lugar de Benjamin poderia ser chamado aos seus princípios por esta entrada sugerida na citação.

Neste espaço, a estética e a política serão os motivos centrais para uma contextualização do ímpeto moderno para a transformação social, e, segundo

asserção, de que o artista era um aristocrata autêntico; que deveria mesmo ser, em seu sentido espiritual, um aristocrata se quisesse de fato se tornar um artista." (WILLIAMS, 2011, 35).

\footnotetext{
${ }^{8}$ Neste complemento incontornável que Williams tece sobre isto, notamos que: "Naturalmente, a burguesia e seu mundo eram objeto de hostilidade e de desprezo por tais opositores, mas asserção não teve de ser feita com muita frequência para ser estendida a uma total condenação da "massa" que estava aquém de todos os artistas autênticos: constituída, agora, não apenas pela burguesia, mas por aquele populacho que se encontrava aquém do alcance da arte era hostil a ela de forma vulgar. Qualquer resíduo de uma aristocracia real poderia, em certas ocasiões, ser incluído nesse tipo de condenação: bárbaros mundanos que eram ofensivamente confundidos com os verdadeiros aristocratas criativos." (WILLIAMS, 2011, 36).
}

Mestrando em Filosofia pela Universidade Federal de Ouro Preto. Brasileiro, residente em Juiz de Fora - MG. Email: rodrigorochadeoliveiracod@gmail.com 
Williams (2011), o conluio que se armava à esquerda estava, por, pelo menos por duas décadas, incrementado de idiossincrasias fabulosas: "Havia primeiramente, uma forte atração por formas tanto de anarquismo e niilismo quanto de socialismo revolucionário, formas que, em sua representação estética, possuíam um caráter comparativamente apocalíptico." (WILLIAMS, 2011, 40). Ao que Williams complementa: "Hostilidade à guerra e ao militarismo também alimentaram essa tendência, dos dadaístas aos surrealistas, e dos simbolistas russos aos futuristas do mesmo país." (WILLIAMS, 2011, 40).

No ponto de toque em que nos questionamos sobre nosso personagem central, dentro dessa breve análise de contexto, Benjamin: neste quadro, preenchido por ambivalências e complexidades, no qual as vanguardas e o modernismo cultural, em paralelo, se desenrolam, qual seria o posicionamento ocupado pelo crítico da literatura Walter Benjamin? Ou ainda, se levarmos em conta o fato de que estas escolas e suas repercussões foram temáticas presentes na contemporaneidade benjaminiana, como o pensador alemão experimentou esse contexto efervescente e como sua crítica social se desenrola sobre a pressuposição dessa tomada estética do modernismo e as vanguardas modernas?

Logo, após destrinchar as oposições entre a vanguarda e o modernismo, e, por conseguinte, entre as objeções que tais movimentos dirigem contra a burguesia, Williams nos fala sobre determinada comunidade na perspectiva dessas escolas que indicam conclusões parciais sobre o tema comparativo que identificamos a esta discussão. Sobretudo, Williams escreve: "Dentro desses caminhos variados, que podem ser trilhados até posições políticas relativamente explícitas, há um conjunto bastante complexo de vínculos que poderiam, aparentemente, seguir quaisquer um dos rumos [Qual seja] pelo recurso de uma arte mais simples." (WILLIAMS, 2011, 41).

Vinculado ao aspecto de valorização da ingenuidade (do "naive") encontrado nas vanguardas, de modo geral, Williams (2011) aponta para uma revalorização do "povo" como símbolo de uma tradição primitiva que será elogiosa. Todavia, a dialética posta em ato nesta incursão pelo passado, teria 
sua negatividade marcada também pela ideologia fascista, que, à sua maneira, inspira uma cultura afirmativa do irracional. ${ }^{9}$

Para pensarmos a concepção de "tradição dos oprimidos", que Benjamin convoca amplamente nas "Teses" essa é uma advertência muito adequada, justamente porque a oscilação imposta pela descrição, entre o racional/préracional, política da violência e força revolucionária, são termos cruciais para nossa leitura.

Porque viemos pensar a memória dos excluídos, questionamos antes 0 que difere esta proposta daquela outra, fragilizada, "tradição popular reprimida", suscetível ao declive, tanto para própria revolução quanto para "outro(s) tipo(s)" de manifestações que sejam, por sua vez, precárias.

Williams (2011) observa o perigo iminente nesse tipo de irracionalismo, anti-político, ao permanecer entregue às "realidades mais profundas da psique dinâmica; e, dentro dessa rejeição, [conceber] uma linha influente de opção pelas formas conservadoras da ordem." (WILLIAMS, 2011, 42). Para Williams os surrealistas abrem uma exceção a esta conformidade niilista - o abismo, no caso da leitura sobre o nascedouro das alegorias - no sentido revolucionário deste mesmo esvaziamento.

Dito isso, conforme escreve o autor: “(...) sua singularidade absorveu, como nenhum outro movimento cultural, aquela tarefa histórica de emancipação. A maioria dos surrealistas na década de 1930 moveu-se em direção a uma resistência contra o fascismo: obviamente uma resistência ativa e perturbadora." (WILLIAMS, 2011, 42). ${ }^{10}$

Nesta panóplia vanguardista da modernidade, o surrealismo redireciona o espírito non sense ao menos para os anseios de uma revolução emancipatória;

\footnotetext{
9 A ênfase no 'povo', quando oferecida como evidência de uma tradição popular reprimida, poderia prontamente mover-se em direção a tendências revolucionárias e radicais tanto socialistas quanto de outro tipo (/) Da mesma forma, contudo, uma ênfase na criatividade do préracional poderia ser cooptada para uma rejeição de qualquer forma de política racional, incluindo não apenas o progressismo liberal, mas também o socialismo cientifico, ao ponto de, em uma versão, a política da ação do forte não refletido ter sido idealizada como necessariamente libertária. (WILLIAMS, 2011, 41-42).
}

\footnotetext{
${ }^{10}$ Neste sentido Williams ainda complementa: "Havia também uma longa (e inacabada) interação entre os psicanalistas, cada vez mais a expressão dessas ênfases "pré-racionais", e o marxismo, a expressão teórica então dominante da revolução da classe operária." (WILLIAMS, 2011, 42).

Mestrando em Filosofia pela Universidade Federal de Ouro Preto. Brasileiro, residente em Juiz de Fora - MG. Email: rodrigorochadeoliveiracod@gmail.com
} 
sua distinção representaria o que foi a ebulição cultural da qual fez parte pelo levante oposicional, o pensamento crítico de Benjamin - como vimos até então, é certo, de forma extremamente particular.

O comentador nos indica, na sequência de sua exposição, outro traço comum às vanguardas na modernidade e ao modernismo cultural, que arrasta para o campo político as querelas estéticas. A saber, o espaço e toda ambientação sociocultural das cidades que também será revisto no temário propriamente benjaminiano.

Também na leitura que Benjamin faz do surrealismo, o ar metropolitano e cosmopolita são algo recorrente e indicam traços de uma crítica social engajada e resistente. O olhar de Benjamin para as cidades remonta ao problema da industrialização, que é, por sua vez, outro dos temas prediletos no repertório da visão melancólica sobre a história moderna.

$\mathrm{Na}$ "tese" de número XI, Benjamin escreve sobre a crença perniciosa no trabalho fabril como mobilização para o progresso e enceta um único fluxo de progressismo para a socialdemocracia e o operariado alemão:

\begin{abstract}
O conformismo que, desde o início, sentiu-se em casa na socialdemocracia, adere não só à sua tática política, mas também às suas ideias econômicas. Ele é uma das causas do colapso ulterior. Não há nada que tenha corrompido tanto o operariado alemão quanto a crença de que ele nadava com a correnteza. O desenvolvimento técnico parecia-lhe o declive da correnteza em cujo sentido acreditava nadar. Daí era um só passo até a ilusão de que o trabalho fabril, que se inserisse no sulco do progresso técnico, representaria um feito político (...) (BENJAMIN, 2005, 100).
\end{abstract}

A cidade, na sua miséria humana, abriga todas as vielas dessa absoluta condição de incertitumbre e, ao mesmo tempo, palpitação pela novidade que acometem a modernidade artística nas suas diversas tendências. Por isso mesmo, tenhamos em mente que Benjamin participa - enquanto escritor e crítico literário - de maneira ativa do espírito vanguardista de transformação radical da sociedade pela arte. ${ }^{11}$

\footnotetext{
11 Sobretudo, façamos nossa aquela conclusão que Raymond Williams (2011) encerra ao falar das vanguardas como fenômenos instigantes até a atualidade, o que, por intermédio de nossa interpretação, vale também para a obra filosófica de Walter Benjamin. Sobre isto, Williams escreve: "Temos então de nos lembrar que apolítica da vanguarda, desde seu início, poderia seguir qualquer um dos dois caminhos [quer dizer, a esquerda revolucionária ou a extrema direita]: a nova arte poderia encontrar seu lugar em uma nova ordem social; ou poderia encontrar Mestrando em Filosofia pela Universidade Federal de Ouro Preto. Brasileiro, residente em Juiz de Fora - MG. Email: rodrigorochadeoliveiracod@gmail.com
} 
Enfim, guardadas todas as considerações proporcionais, a definição que Williams sugere para as vanguardas poderia ser aplicada como cadência para nossa leitura benjaminiana a partir dessa breve entrada - porque Williams escreve: “(...) a vanguarda, como movimento artístico que incorpora simultaneamente uma campanha política e uma campanha cultural" (WILLIAMS, 2011, 46).

\section{A melancolia como termo estrutural na filosofia da linguagem benjaminiana}

No livro sobre a Origem do drama barroco alemão, de 1925, Benjamin sugere uma organização tipicamente dialética, tanto para a totalidade da obra, quanto para suas partes internas, inclusive decide-se por uma divisão tripartite para suas seções. ${ }^{12}$ Para fazermos a transição suposta, da primeira seção do bloco sobre as alegorias até a última parte, sua síntese decidimos retomar algumas questões relevantes. Questões que reúnem, no bojo de suas inventivas, o tema da promessa redentora com as implicações sobre o trânsito que o objeto sagrado protagoniza, uma vez lançado no intermédio linguístico do reino profano. As ideias descendem e têm sua perfeição maculada. Esse salto específico - que nos prepara para a compreensão da melancolia —, que devém como resultado do apuramento da expressão alegórica, é o que viemos mostrar

seu lugar em uma velha ordem social, culturalmente transformada, mas, sobre outros aspectos, persistente e restaurada. O que era de fato muito certo, desde as primeiras agitações do modernismo até as formas mais extremas da vanguarda, era que nada poderia se manter como estava: que as pressões internas e as contradições intoleráveis forçariam mudanças radicais de algum tipo. Além das direções e aflições particulares, essa é ainda a importância histórica desse grupo de movimento de artistas individuais e notáveis. E uma vez que as pressões e contradições gerais ainda não intensas, embora de modo diverso, e têm, de várias formas, se intensificado, há ainda muito a aprender com as complexidades de seu desenvolvimento vigoroso e surpreendente (WILLIAMS, 2011, 47).

12 Esta constatação é inspirada naquela passagem que Bernd Witte registra na biografia de Walter Benjamin: "Em meados de setembro de 1924, pode escrever a Scholem que havia terminado 'a introdução epistemológico-crítica do trabalho, o primeiro capítulo, 'O rei no drama trágico', e praticamente também o segundo, 'Drama trágico e tragédia', de modo que resta ainda escrever o terceiro, 'teoria da alegoria', e uma conclusão. Nessa fase do trabalho Benjamin pretendia fazer, portanto, uma ordenação classicamente dialética do material, três passos, de modo que a alegoria apareceria como síntese, e por isso como a realização da intenção pretendida na análise do drama trágico." (WITTE, 2017, 60). Reconhecemos aqui uma tomada interessante para abordagem do texto.

Mestrando em Filosofia pela Universidade Federal de Ouro Preto. Brasileiro, residente em Juiz de Fora - MG. Email: rodrigorochadeoliveiracod@gmail.com 
neste artigo. Ao fazermos valer esta breve lembrança retrocedemos àquilo que, por causa da crítica específica à subjetividade moderna, atrela a este também o problema sobre a origem da linguagem ao papel subjetivo no horizonte de uma filosofia que trabalha com a exposição genuína da verdade e sob uma estruturação linguística que seja, enfim, correspondente a este primeiro motivo. No limite, voltamos a um reclame benjaminiano por determinada epistemologia resistente da modernidade, uma vez que é contraditória a cientificidade instrumental e progressista, como vertentes centrais para sustentação das bases iluministas do progresso.

Patricia Lavelle, no artigo intitulado "A árvore e o juízo: As raízes criticistas da filosofia da linguagem de W. Benjamin", publicado em 2009, explora este mesmo temário apoiada na leitura de Sobre a linguagem em geral e sobre a linguagem humana. Lavelle instiga essa fronde, após declarar que, se fossemos "diretamente às fontes kantianas do pensamento de Benjamin, o problema do sujeito (sua crítica no texto programático de 1917 e sua redenção alegórica no final do livro sobre o drama barroco alemão)" (LAVELLE, 2009, 95), isso exigiria uma revisão especial sobre o conceito de juízo. Isto porque, se na sua constituição subjetiva a essência espiritual do homem é manifestada na capacidade de nomear as coisas, este processo nominativo exigirá uma prerrogativa dada ao juízo. O juízo atua, deste modo, na transfiguração efetiva da linguagem paradisíaca em uma linguagem meramente humana, digamos assim. Ou seja, além de estar absorvido pela incerteza que desola o observador melancólico, com esta possibilidade da linguagem como idioma e comunicação no mundo dos homens, no plano reto de todas as coisas brutas e materiais, seu fim será posto na mortificação. Esta, que será concretizada historicamente na sua forma mais perversa, por aquela atitude superlativa que será o flagelo corporal praticado pelo cristianismo medieval, como correção aos pecados dos homens. O juízo que, como intermédio das coisas até sua nomeação, permanece por vir. Presente no movimento de declínio dos objetos que descendem ao mundo terreno, quando no estado cristalino de sua suspensão perdurável, emerge transportando aquilo que não o contamina. O juízo, que precede à linguagem do homem após a queda adâmica, e será, portanto, uma das raízes críticas fundamentais na filosofia benjaminiana da linguagem, Mestrando em Filosofia pela Universidade Federal de Ouro Preto. Brasileiro, residente em Juiz de Fora - MG. Email: rodrigorochadeoliveiracod@gmail.com 
supondo um esquema (mental e de sensibilidade) revolucionário. Afinal, não somente conceberíamos, a partir do juízo, o homem na sua essência espiritual linguística, como também o juízo o designa a sua intrínseca aliança teológica. No revés do ideal paradisíaco, - em que a linguagem seria evidência e conhecimento, igualmente perfeição e indiferença amorfa - contudo, o sujeito (exemplar) barroco se depara com a integração do método desviante instalado nas bases da sabedoria alegórica.

$\mathrm{Na}$ leitura de Lavelle, o conceito de juízo é incontornável para pensarmos uma revitalização da teoria iluminista do conhecimento que, ao reduzir sua intervenção ao "paradigma físico-matemático de experiência", teria se tornado inócua (LAVELLE, 2009, p. 96). A solução para o problema estaria, afinal, na virada linguística hammaniana, que vai muito além dos esquemas cientificistas regentes. Isto porque, Hamann tem prevista sua contraprova n' "o caráter linguístico do sujeito transcendental kantiano", retido, finalmente, como evidência (LAVELLE, 2009, 96). Desta maneira, retomar o conceito de juízo, neste círculo hermenêutico, significa dar premência linguística a uma teoria do conhecimento que preze "uma concepção bastante alargada da linguagem" enquanto "médium da experiência e do pensamento" (LAVELLE, 2009, 97). Sobretudo, Lavelle acrescenta uma descrição comparativa sobre a função do juízo e do nome — na filosofia benjaminiana sobre a linguagem - que acrescenta detalhes importantes a entrada que sugerimos. Principalmente, quando Lavelle conclui que "o sujeito pode apenas não fazer da linguagem um meio de comunicação, mas também conhecer objetivamente a natureza e pensar os conteúdos abstratos que reenviam imediatamente ao 'colocar-se em forma' do pensamento no juízo" (2009, 97), Lavelle reforça este paradigma do qual falamos. Entrementes, o juízo estipula uma faixa especulativa por onde o ser das coisas e sua nomeação crivam esta afinidade primária com o mundo das ideias; com o paraíso das significações perfeitas, com a palavra divina, etc. Porque o juízo intervém para converter uma linguagem, de nascimento paradisíaca, porém, integrada agora numa nova forma fragmentária e temporal, quando sim, histórica. Uma linguagem melancólica do seu próprio salvamento, desde sempre agourado - ao seu modo, precisamente benjaminiano - e gestado na 
penumbra da dúvida sobre os sentidos em dispersão que são recolhidos das ruínas. ${ }^{13}$

Em torno do enlace teórico que ata o nascimento da linguagem ao surgimento da história, no advento da linguagem pronunciada sobre o enclave do juízo, Lavelle escreve o seguinte - neste tópico que é igualmente proposto num território extensivo à estética, à teologia, à política, etc.:

\begin{abstract}
Neste sentido, se o nome corresponde à unidade entre a matéria e a forma da experiência no médium da vida, a duplicidade do signo é a consequência da fragmentação que, implicando a separação entre o sujeito e o objeto, vem do uso das palavras no juízo. Nesta perspectiva, a cisão entre significado e significante, que caracteriza o signo e funda a possibilidade da história como fragmentação da unidade do sentido numa sucessão de significações, surge da articulação lógica das palavras no juízo. (LAVELLE, 2009, 98).
\end{abstract}

Dito isto, constatamos que Benjamin começa a terceira seção do capítulo sobre as alegorias, em "Origem do drama barroco alemão", com uma descrição ao estilo prismático sobre o peso que o juízo incorpora a "história como fragmentação da unidade do sentido numa sucessão de significações" (BENJAMIN, 2013, 98). Assim, quando Benjamin (2018) escreve que, "em última análise", a substância que o drama trágico precisou assimilar o mais profundamente, por atender as condições materiais de sua época, foi a expressão alegórica, isso faz do conceito de juízo interposto o esquema antecipado de sua fragmentação. Seu produto epistêmico, invento do contato entre o paraíso e a terra, nos oferece uma chave hermenêutica preciosa - a qual Benjamin (2013) também utiliza - para abrir o caminho ontológico sobre

\footnotetext{
13 Novamente, a esta altura, poderíamos nos remeter à noção de constelação, porque, principalmente no livro que tomamos por base nesta leitura, "Origem do drama barroco alemão", as ideias estão intrinsecamente relacionadas às constelações, e também pela remissão ao aspecto da transitoriedade que, de novo, circunscreve essa discussão: das constelações que são passageiras e fugazes assim como as ideias em sua condição "constelacional". Sobretudo, como Benjamin escreve no prefácio do livro: "O conjunto dos conceitos que servem à representação de uma ideia "presentifica-a" como configuração daqueles. De fato, os fenômenos não estão incorporados nas ideias, não estão contidos nelas. As ideias são antes a sua disposição virtual e objetiva, são a sua interpretação objetiva [...] O seu significado pode ser ilustrado por meio de uma analogia. As ideias relacionam-se com as coisas como as constelações com as estrelas. Isto significa desde logo que elas não são nem os conceitos nem as leis das coisas. Não servem para o conhecimento dos fenômenos, e estes de nenhum modo podem servir de critério para a existência das ideias [...] As ideias são constelações eternas, e se os elementos se podem conceber como pontos em tais constelações, os fenômenos estão nelas simultaneamente dispersos e salvos." (BENJAMIN, 2013, 22-23).
}

Mestrando em Filosofia pela Universidade Federal de Ouro Preto. Brasileiro, residente em Juiz de Fora - MG. Email: rodrigorochadeoliveiracod@gmail.com 
uma experiência da tradição na modernidade: tradição como conhecimento transmitido na contrapartida de uma experiência vulgata transcorrida na temporalidade esvaziada pela ideologia do progresso. A expressão alegórica se torna o fruto teológico da árvore do conhecimento, envolvido pela estética que somente o barroco poderia lhe designar. O paradoxo de sua confluência é absoluto porque, como escreve Benjamin, "só poderemos libertar criticamente a forma-limite alegórica do drama trágico da dependência da esfera mais alta, a teológica, enquanto que numa perspectiva estritamente estética a última palavra tem de pertencer ao paradoxo" (BENJAMIN, 2013, 233-234).

Desde a atmosfera catastrófica relacionada ao universo alegórico das significações, esta compraz uma práxis derivada de preceitos barrocos por enredos que aproximam valores estéticos de valores teológicos, políticos e sociais. Por isso, sublinhamos a percepção do corpo humano e da morte como assunto seleto para o Benjamin de 1925, leitor do barroco, tendo em vista, certamente, as conclusões que anunciamos até então. Na sequência do texto, ao falarmos sobre o aspecto fúnebre como algo que será intermediado, no caso do drama trágico, por uma relação estética operante no interior deste âmbito sumariamente teológico, Benjamin expõe o seguinte:

\begin{abstract}
Particularizaremos: que significado atribuir àquelas cenas de horror e martírio que abundam nos dramas do Barroco? É fraco o afluxo de respostas que brotam das fontes da própria crítica de arte barroca, ingênua e irrefletida. Há algumas respostas escondidas, mais valiosas: Integrum humanum corpus symbolicam iconen ingredi non posse, partem tamen corporis ei constituendae non esse ineptam [O corpo humano não pode integrar um ícone simbólico, mas uma parte do corpo pode ser apropriada à constituição desse ícone]. É o que lemos na exposição de uma controvérsia sobre as normas da emblemática. O autor de emblemas ortodoxo não podia pensar de outro modo: o corpo humano não podia ser exceção àquela regra que diz que é preciso desmembrar o orgânico para recolher dos seus estilhaços a sua verdadeira significação, fixa e escritural. E onde poderia esta lei encontrar uma aplicação mais triunfal do que no ser humano, que abandona a sua physis convencional, dotada de consciência, para dispersar pelas múltiplas regiões da significação? (BENJAMIN, 2013, 234).
\end{abstract}

A proposição metodológica que o excerto anuncia é correspondente ao que, no "Discurso do método", publicado em 1637, René Descartes endossa: tangenciando os objetos compreendidos como substratos infinitesimais para uma apreensão conceitual clara e distinta. Porém, como vemos adiante, essa Mestrando em Filosofia pela Universidade Federal de Ouro Preto. Brasileiro, residente em Juiz de Fora - MG. Email: rodrigorochadeoliveiracod@gmail.com 
não será aquela afinidade que Benjamin destacaria. Todavia, Benjamin escreve na sequência do argumento: "Não é apenas o dualismo cartesiano que é barroco; também a teoria das paixões tem de ser levada em conta, e muito como consequência da doutrina das relações psicofísicas." (BENJAMIN, 2013, 235). Sendo o problema intrínseco a este dualismo colocar em voga uma divisa ontológica inculcada por outra incerteza, agora concernente a unidade corpo/alma, será o corpo o que irá sofrer diretamente as consequências dessa incógnita. Isto porque na realização do contato "psicofísico", o corpo martirizado se torna, muito pela sensibilidade imediata à dor, mais próximo do sentimento desejado que qualquer contemplação teórica poderia alcançar. Sobre isto, Benjamin escreve: "Quando o espírito, como espírito que é, se liberta pela morte, também o corpo vê satisfeitos todos os seus direitos. Porque é óbvio que a alegorização da physis só pode consumar-se em toda a sua energia no cadáver." (BENJAMIN, 2013, 235). Motivo pelo qual o filósofo complementa: "Do ponto de vista da morte, a função da vida é produção do cadáver." (BENJAMIN, 2013, 235). Ou seja, Benjamin instaura uma sequência de inversões, fixados neste estranho imaginário do direito à morte como legado barroco único. Benjamin elenca as palavras que correspondem ao núcleo da sensibilidade barroca, aliás, a partir do "corpo no processo de envelhecimento", ou, "[dos] processos de eliminação e depuração [em] que o cadáver se vai desprendendo do corpo" $(2013,235)$. Se pensarmos na influência desta visão para o caso de uma poética barroca, todo este repertório escatológico será privilegiado entre os artistas desse período.

Na análise que faz de Lohenstein (1635-1683), Benjamin escreve: "Já as primeiras produções de Lohenstein dão testemunho curioso deste curioso tema poético" $(2013,236)$. A saber, o tema da morte e o cadáver como afecções de um corpo passível à mutilação e aos castigos no cabo de um processo de autocrítica de sua condição funesta. Em "Denck-und Danck-Altar [Altar de memória e gratidão]", segundo o filósofo, a composição de sua poesia é feita de "Nove estrofes absolutamente impiedosas [e] descrevem as partes do cadáver em estado de decomposição." (BENJAMIN, 2013, 236). Essa perspectiva, voltase, então, para o estado putrefato da carne, os seus "estilhaços", o seu perecimento, e sempre na linha de fuga da vida eternizada, porém, Mestrando em Filosofia pela Universidade Federal de Ouro Preto. Brasileiro, residente em Juiz de Fora - MG. Email: rodrigorochadeoliveiracod@gmail.com 
contraditoriamente a vislumbrando pelas frestas do juízo. ( $O$ que culmina naquela tensão dialética entre o eterno e o mortal). Sobre Griphius (1616-1664), Benjamin afirma que: “(...) deve ter considerado [Griphius] tais composições muito atuais, e certamente o seu estudo da anatomia, a que sempre permaneceu fiel, foi largamente determinado, a par dos interesses científicos, por estes outros, estranhamente emblemáticos." (BENJAMIN, 2013, 236). Logo, Benjamin desenha um triângulo afetivo comum às visões cristã e barroca, ao elaborar sua interpretação sobre o paganismo que lhe fora marginalizado pelas seguintes palavras: "As afinidades de fato entre a cristandade medieval e a barroca são de tripla ordem. Para ambas são igualmente essenciais a luta contra os deuses pagãos, o triunfo da alegoria e o martírio do corpo." (BENJAMIN. 2013, 238). A nudez, igualmente considerada causa do pecado, coaduna para uma escamoteação definitiva do universo barroco e cristão, envergado completamente para introjeção da culpa.

Antes de chegarmos ao desdobramento específico sobre a culpa também para a melancolia, vejamos o que Benjamin anota sobre o objeto alegórico transparecido por completo na sua carnadura sacrificada: "Como do exposto se pode depreender, a exegese alegórica apontava sobretudo em duas direções: destinava-se a dar uma leitura cristã a verdadeira natureza, demoníaca, dos deuses antigos, e servia para mortificação devota do corpo." (BENJAMIN, 2013, 240). Retrato este que, inclusive, sustenta a ideia das alegorias distanciadas, como deve ser, de uma ornamentação poética por si, quando sim, estas seriam uma expressão fiel ao combate direto ao paganismo antigo. Nas palavras de Benjamin - ao falar sobre o espírito aguerrido do barroco frente aos antigos: "Ela não é, de fato, o monumento epigonal de uma vitória: é antes a palavra capaz de exorcizar um resíduo ainda intacto da vida dos Antigos." (BENJAMIN, 2013, 241). Desta aversão, já na primeira metade da era cristã, uma consequência perceptível sobre o modo alegórico será o abstracionismo, alienado dos fundamentos integrados que os emblemas tinham na sua virtude originária. Por isso, na passagem seguinte, Benjamin (2013) descreve o conteúdo de uma interpretação muito datada sobre a concepção alegórica a fim de designar sua recuperação urgente. 
Tudo isto prepara de forma intensa o caminho para a alegoria. Mas, se ela é mais que a dissipação, por abstrata que seja, das essências teológicas, concretamente a manutenção delas num espaço que não Ihe é adequado, e lhes é mesmo hostil, também esta concepção romana tardia não é a verdadeira concepção alegórica. Na sequência dessa literatura, o mundo dos deuses antigos teria morrido, quando na verdade foi a alegoria que o salvou, se pensarmos que a visão da transitoriedade das coisas e a preocupação de as salvar para um eternidade é um dos mais fortes motivos do fenômeno alegórico. (BENJAMIN, 2013, 241).

Acolhido pela forma alegórica, o paradoxo - como lemos na passagem anterior - redime os deuses antigos e, como deuses que são, não morreriam por uma facticidade. Pelo contrário, a concepção da morte, no caso dos deuses, nos remete ao aspecto fixante das formas latentes nos emblemas, como pulsão de sua temporalidade dialética e, também, no espectro do seu teor material. Neste sentido, dois indícios históricos desta perspectiva sobre a finitude nos ajudam na compreensão da morte para o conjunto social do mundo barroco: a Guerra dos Trinta Anos, como imposição opressiva do perecimento ao homem europeu, e as mudanças nas normas jurídicas, pretensamente concatenadas a valores "eternizantes" (BENJAMIN, 2013, 241-242). Por isso, Benjamin escreve: "A alegoria instala-se de forma mais estável nos momentos em que o efêmero e o eterno mais se aproximam." (BENJAMIN, 2013, 242). Mesmo que a Antiguidade a tivesse experimentado, como nas palavras de Benjamin: "[...] a alegoria propriamente dita é sempre cristã" (BENJAMIN, 2013, 242). Acerca disso, destacamos então que a expressão alegórica, além de intermediar dialeticamente o tempo, predispõe o contrapeso da culpa na experiência do sujeito moderno, atraindo sua subjetividade para a integralidade nuclear encontrada na teologia. Na passagem que escolhemos, a culpa é descrita, primeiro como sentimento imanente ao contexto desviante de incompreensão sobre os regimes significantes instituídos pela ordem, par e passo, a determinada singularidade de uma natureza que reclama por ser redimida: "A culpa impede o objeto que significa alegoricamente de encontrar em si mesmo a concretização do sentido. A culpa é imanente, não apenas ao contemplador alegórico, que trai o mundo levado por sua vontade de saber, mas também ao objeto de sua contemplação." (BENJAMIN, 2013, 242). Sendo que, a alegoria como promessa da redenção, lançada no âmago dessa culpabilidade melancólica, tomará a forma do conteúdo histórico como ânimo concernente ao Mestrando em Filosofia pela Universidade Federal de Ouro Preto. Brasileiro, residente em Juiz de Fora - MG. Email: rodrigorochadeoliveiracod@gmail.com 
seu processo, o mais desenvolto no exercício da especulação que move seu repertório imagético. E se, desdobrada pela melancolia, por sua vez, uma alegoria recobre o perímetro entre a dispersão, o espectro das coisas concretas e a redenção, portanto, concebemos a figuração de sua intencionalidade última.

Como escreve Benjamin, o arquivo de imagens alegóricas se transmuta numa intenção melancólica, que assegura, antes de mais nada, a condição "coisal do objeto":

Por outro lado, quanto mais a natureza e a Antiguidade eram sentidas como culpadas, tanto mais obrigatória se torna a sua intepretação alegórica, apesar de tudo a sua única redenção possível: pois, apesar de desvalorizar conscientemente, a intenção melancólica mantém de forma incompatível a fidelidade à condição coisal do objeto. (BENJAMIN, 2013, 242).

A expressão alegórica, destarte, a intenção melancólica, revoluciona 0 absurdo das figuras da morte no retorno direto aos objetos pelos quais sua invenção emblemática traz à tona novos sentidos imagéticos que serão estacados na finitude imanente a sua construção. Por isso, dissemos que esta é uma redenção às avessas", porque se configura num "retorno às coisas mesmas pelo crivo da finitude - para fazermos menção a esse princípio metodológico da fenomenologia - pelos olhos daquele que enxerga a realidade subsumida no que jaz morto. No defunto, que está paralisado à sua frente - assim como seria fixado um emblema - e que apreende, na sua conceituação, a possibilidade de ingerir o tempo que o atravessara, desde a memória do passado. Todavia, Benjamin precisa voltar atrás e nos precaver de que, essa transformação teórica flagrante na estética barroca não foi alcançada por seus contemporâneos plenamente, ou, na vida de modo geral - pelo menos não de maneira consolidada. Mesmo a suposta afeição tranquila frente aos vultos da Antiguidade não foi concebida como tal, ao invés disso, os medievais receberam os deuses antigos com extrema obscuridade e rejeição. Nas palavras de Benjamin: "[...] os três momentos fundamentais da alegorese ocidental são não antigos, antiantigos: os deuses invadem o mundo estranho, tornam-se malignos e transformam-se em criaturas." (BENJAMIN, 2013, 243). Da personificação dos deuses e a possibilidade da sua encarnação enquanto conquista do perecimento humano, o detrito deste afastamento, entre antigos e medievais, será impingido pela formulação do seu objeto materializado na exploração de imagens e passa 
a ser encarado como domínio estrito de uma mística periférica. Segundo Benjamin: "Assim a desvalorização dos deuses, degradados a uma condição meramente humana, associou-se cada vez mais à ideia de que nos restos do seu culto, sobretudo nas suas imagens, continuariam a atuar forças mágicas malignas." (BENJAMIN, 2013, 243). Sobretudo, Benjamin defende que, o espírito satânico, na expressão alegórica, foi arrogado ao longo da história por causa de uma visão sobre o mundo helênico, uma visão que não condiz com sua tradição de maneira mais visceral.

Primeiro, porque "os pressupostos para a transformação do panteão antigo num mundo de criaturas mágico-conceituais são, assim, a extinção das figuras e a sua redução a conceitos" (BENJAMIN, 2013, 244). E sobre isto, Benjamin faz uma citação a Aby Warburg, que consideramos um motivo exemplar do caminho "a contrapelo", no sentido de voltar ao paganismo, que pela tinta de Winckelmann havia sido encoberto da história oficial - para quem a tradição pagã domina seu lugar de representação, mesmo no auge da modernidade:

\begin{abstract}
'O nobre mundo clássico dos deuses antigos estão tão presente em nós, desde Winckelmann, como símbolo da Antiguidade, que nos esquecemos completamente de que ele é uma invenção da cultura humanista erudita; esse lado 'olímpico' da Antiguidade teve primeiro de ser arrancado e forma tão decisiva a sua vida prática que é impossível negar a vigência paralela, tacitamente tolerada pela Igreja, da cosmologia pagã, em especial da astrologia.' (WARBURG apud BENJAMIN, 2013, 244).
\end{abstract}

A partir dessa afinidade alegórica com o mundo terreno e passageiro, será alardeada, então, a promessa redentora materializada no emblema, por uma atitude singular no campo de forças, disputado por antigos e medievais. Esta materialização pretende decantar os objetos banhados por elementos metafísicos, repostos numa materialidade despojada - o que seria o desafio de época para os barrocos. Tanto é assim que, como registra Benjamin (2013), o sujeito melancólico, ao realizar sua interpretação, tendo em conta essa premissa inabalável da fixação emblemática, aproxima-se mais do matemático que do metafísico. Nas palavras de Benjamin, entre o emblema e o homem, a escolha melancólica não hesitaria em eleger o objeto individualizado e imóvel dos emblemas: "Quando a intenção alegórica se orienta para o mundo criatural das 
coisas, das coisas mortas, no máximo meio vivas, o homem não aparece no raio de visão." (BENJAMIN, 2013, 245). Os emblemas realizam plenamente sua materialização, porque: "Se ela [a intenção alegórica, que a melancolia exprime como sentimento do mundo] se fixar unicamente nos emblemas, a metamorfose e a redenção não serão impossíveis" (BENJAMIN, 2013, 245). Todavia, nesta dialética em que o intérprete melancólico vislumbra os conceitos despregados de uma realidade concreta, precipita-se, então, outra etapa sintética no centro do problema em torno das significações. Uma interface que sempre esteve presente, mas, de repente, nos aparece como tão inesperada. A saber, a negação e o rapto da própria alegoria em virtude de uma figuração emblemática do maligno, que a fulmina, e coloca em jogo o posto que o mal ocuparia no seu lugar não alegórico. Como se tivéssemos asseverado, definitivamente, a presença do ser do mal - que já não é metafórico —, após termos expulsado de nosso arquivo imaginário uma noção de alegoria do mal com repercussões inclusive de sua superação.

\title{
3 A "redenção às avessas" como figura primordial da Revolução
}

$\mathrm{Na}$ passagem em que Benjamin se remete a esta possibilidade de materialização da intenção melancólica, lemos uma aproximação do barroco a determinado materialismo primário, que será descrito por parte do intérprete melancólico:

\begin{abstract}
Mas pode sempre acontecer que diante do olhar do alegorista se erga, vinda do seio da terra, a verdadeira face do demônio, rindo-se de todos os disfarces emblemáticos, na sua vitalidade e nudez triunfantes. Só a Idade Média gravou na antiga cabeça demoníaca, originalmente muito maior doutrina gnóstico maniqueísta, para "destartarizar" o mundo, absorvendo em si o diabólico para que, com sua eliminação, o mundo se pudesse apresentar purificado, toma consciência, através do diabo, da sua natureza 'tartárica', zomba da sua 'significação' alegórica e escarnece de todos aqueles que julgam que podem investigar impunemente os seus mais fundos arcanos. Assim, do mesmo modo que a tristeza terrena pertence à alegorese, também a jovialidade infernal faz parte da sua nostalgia gorada pelo triunfo da matéria. Daqui vem a jocosidade infernal do intriguista, o seu intelectualismo, o seu saber das significações. A criatura muda é capaz de ter esperança na redenção que the é prometida pelas coisas significadas. (BENJAMIN, 2013, 245).
\end{abstract}

Como escreve Benjamin, a "gargalhada estridente", ouvida agora em alto e bom som, provinda do reino satânico, mantém-se em riste e conflituosa perante Mestrando em Filosofia pela Universidade Federal de Ouro Preto. Brasileiro, residente em Juiz de Fora - MG. Email: rodrigorochadeoliveiracod@gmail.com 
a visão alegórica, neste sentido, porque sua auto aniquilação também é seu modo de existir. Acima de tudo, assume uma forma irreverente e faz oposição àquele mutismo imposto pela culpa, quando este supreendentemente extrapola seu meio linguístico com recurso extremado ao aparelho gutural. Segundo Benjamin: "Nesse riso, o mutismo da matéria é superado. É precisamente no riso que a matéria ganha espírito, de forma exuberante, distorcida e a centrada. $\mathrm{E}$ torna-se tão espiritual que vai além da linguagem, quer chegar mais alto e acaba na gargalhada estridente. (BENJAMIN, 2013, 246). O diabo, que não permite impunemente, em absoluto, quaisquer zombarias contra ele - de acordo com o escritor judeu e alemão Julius Leopold Klein (1810-1876), quando referenciado por Benjamin - seria então, o elemento primordial na figuração barroca. Ainda na esteira de Klein, Benjamin (2013) elabora comentários em torno dos seus textos e, mais especificamente, sobre a importância que o primeiro relegaria à função dessa estirpe alegórico-diabólica na obra de William Shakespeare (15641616). Sobre isso, Benjamin escreve: "Uma das mais poderosas figuras de Shakespeare, como este historiador da literatura sugeriu em excelentes comentários [Justamente ao falar de Klein], só é compreensível a partir desse ponto de vista da alegoria, a partir do satânico." (BENJAMIN, 2013, 246). E na sequência do argumento, Benjamin desmantela também determinada visão do Sturm und Drang sobre as alegorias shakespearianas, ao escrever o seguinte:

Já o Sturm und Drang, que descobriu Shakespeare na Alemanha, só vê nele o elementar, mas não o alegórico. E no entanto, o que caracteriza Shakespeare é o fato de que esses dois lados são igualmente essenciais na sua obra. Toda a manifestação elementar da criatura ganha significação através da sua existência alegórica, e tudo que é alegórico a recebe através do elementar no mundo dos sentidos. (BENJAMIN, 2013, 247).

Apesar do romantismo ter seu opúsculo alegórico tardiamente, a interpretação que o movimento romântico teceu sobre o universo barroco foi acometida por esta distorção perspectiva segundo a leitura de Benjamin que viemos analisar (2013). Isto é, Ihe escapa inicialmente o quesito da anteposição precisa para o binômio elementar/alegórico - como acontece na "manifestação elementar da criatura" e sua "significação alegórica" na obra de Shakespeare. E sem que ambas estejam, necessariamente, apartadas uma da outra, estas duas interfaces do drama shakespeariano, afinal, acabam sendo perdidas pelos Mestrando em Filosofia pela Universidade Federal de Ouro Preto. Brasileiro, residente em Juiz de Fora - MG. Email: rodrigorochadeoliveiracod@gmail.com 
românticos. Como escreve Benjamin: "O Romantismo voltou depois a ter depois uma intuição do alegórico. Mas, naquilo em que depende de Shakespeare, não foi além dessa intuição do alegórico.” (BENJAMIN, 2013, 247). Na descrição panorâmica que faz Benjamin (2013), será Calderón de la Barca (1600-1681) quem representa, até certa medida, o espírito alegórico não atingido por Shakespeare - pelo menos não como compreensão mais profunda no mundo barroco. O dramaturgo barroco espanhol, de la Barca, por sua vez, instaura o intuito alegórico sobre os pilares de uma sabedoria desprovida até mesmo da busca pela verdade, quando sim, apega-se ao burburinho e à especulação divagante do saber pelo saber. Afinal, como Benjamin escreve: "A intenção alegórica é de tal modo contrária à busca da verdade, que nessa intenção se manifesta, de forma mais clara que em qualquer outra situação, a unidade resultante de uma curiosidade pura, que visa o mero saber." (BENJAMIN, 2013, 247). Sua resultante, inscreverá um retorno ao mágico na mesma medida e grau que também viveram os renascentistas, mas agora para uma experiência da modernidade. Portanto, há no mundo barroco uma proliferação inegável das significações sob os cuidados do personagem alquimista que se repete como signo exemplar da proximidade estrutural nos períodos distintos (Renascimento/Barroco).

A sabedoria barroca e o mal se tornam o escopo de uma redenção alegórica que foi canalizada no acontecimento da intenção melancólica sobre o mundo errante das coisas vãs. Este mundo que se nos mostra multifacetado e sempre às vésperas da extinção. Como nas palavras de Benjamin: "A disposição anímica dominante nela [quer dizer, na alegoria] é a do luto, a um tempo mãe e conteúdo das alegorias." (BENJAMIN, 2013, 248). Luto e melancolia, assim como para a salvação e a culpa, são um complexo predisposto à percepção barroca da história. O sentimento da morte e a tristeza nos olhos de quem reencontra em tudo a sua perda, são a tônica da cosmovisão que sustenta, então, o barroco. Deste modo, quanto mais próximo da escassez expressiva, o escarnecido saber profano imita uma síntese da vida real, que é falseada, então, por uma consciência e matéria replicadas e mimetizadas. Para termos uma ideia do quão potencialmente abstratas serão suas reflexões, nas palavras de Benjamin, entrevemos logo que: "A espiritualidade absoluta, assim atribuída a Mestrando em Filosofia pela Universidade Federal de Ouro Preto. Brasileiro, residente em Juiz de Fora - MG. Email: rodrigorochadeoliveiracod@gmail.com 
Satanás, suicida-se no ato de emancipar do sagrado [...] O absolutamente material e aquela espiritualidade absoluta são polos do domínio satânico: e a consciência é a sua síntese ilusória, por meio da qual ela imita a verdadeira, a da vida." (BENJAMIN, 2013, 248-249). Instalada, portanto, no arcabouço deste simulacro, essa falsa consciência forja uma compreensão absoluta, porque, no seu turno, pretende uma consciência que não hierarquize os objetos do seu interesse e, furta cada pequeno objeto ao seu repertório de ruínas, como sinal de uma elucubração profana. Um saber que se esgota paradoxalmente para se proliferar. Ou seja, um saber que, para se proliferar nas figuras de sua livre especulação, sustém o corpus do seu método no cortejo do próprio desvão dado por um recorte abrupto na realidade. Porque, como conclui Benjamin: "Mas a sua especulação estranha à vida, presa ao mundo coisal dos emblemas, acaba por atingir o saber dos demônios." (BENJAMIN, 2013, 249). Motivo pelo qual, enfim, São Francisco de Assis (1182-1226) aconselha, - na curiosa menção que Benjamin faz - a uma precaução sobre o aprofundamento nos estudos de modo geral: "E S. Francisco de Assis condenou em termos altamente espirituais o fanatismo espiritual. Aponta o caminho certa a um dos seus discípulos que se encerrava em estudos demasiado profundos: Unus solus daimon plus scit quam tu [Um só demônio sabe mais que tu]." (BENJAMIN, 2013, 249).

Por isso é mesmo Benjamin escreve ainda: "Querer separar o tesouro de imagens com as quais se dá a reviravolta no sentido do paraíso da redenção daquele outro, sombrio, que significa morte e inferno, seria desconhecer totalmente a essência do alegórico." (BENJAMIN, 2013, 250). Sobre isto, as palavras de Benjamin são insubstituíveis na sua precisão em torno disso que chamamos, "redenção às avessas" - expressões como "reviravolta redentora" e "salto mortal para trás", que estão nas linhas de "Origem do Drama barroco" explicam melhor do que quaisquer outras este acontecimento. Neste ponto, vejamos os esforços de Benjamin para dizer o estado absoluto de rebelião no mundo Barroco das significações:

A desolada confusão dos ossuários que pode ser lida como esquema das figuras alegóricas em milhares de gravuras e descrições da época, não é apenas símbolo da desolação de toda a existência humana. Aí a transitoriedade não é significada, alegoricamente representada; é antes, em si mesma significante, apresentada como alegoria. Como alegoria da ressurreição. Por fim, nos monumentos fúnebres do 
Barroco, a contemplação alegórica opera uma reviravolta redentora, uma espécie de salto mortal para trás. (BENJAMIN, 2013, 250, grifo nosso).

Por outras palavras, poderíamos dizer, vemos acontecer exatamente um looping. Um movimento em que, a narrativa histórica, antes de mais nada, como estado de vigília sobre a transitoriedade, faz do conteúdo alegórico, na sua condição passageira, certa figura redentora por assunção. Seu não-lugar, sua dor irremediável, reconhecida por nós no "olhar absorto do sujeito melancólico", ou, no lugar de estar "à beira do abismo", não se mostra contrário a esta noção de redenção porque, neste espaço, serão redimidas todas as lutas inglórias. Nas teses Sobre o conceito de história, texto de 1940, a partir da revelação dos objetos ínfimos, visivelmente na tese de número III, o tema do modo especulativo aparece vinculado a uma noção ampla do risco iminente nesta posição do inquiridor. Motivo pelo qual Benjamin escreve, logo na primeira linha do texto: "O cronista que narra profusamente os acontecimentos, sem distinguir grandes e pequenos, leva com isso a verdade de que nada do que alguma vez aconteceu pode ser dado por perdido para a história." (BENJAMIN, 2005, 54). Sobretudo, mais adiante no texto, o "Juízo Final", conforme escreve Benjamin (2013), inverte os olhares sobre a história porque reclama por aqueles objetos escassos que a modernidade excreta como escombro, no alto largo do progresso. Sua transformação, portanto, não descende do esvaziamento nos sentidos, porém, esvazia-se dos sentidos monolíticos para gerar outros, certamente, os mais fragmentários e escarnecidos, mas expressivos da luta oprimida. Michael Lowy (2005) ao escrever sobre o peso da moralidade política em relação ao exercício da memória dos antepassados, que esperam ser reconhecidos nos seus atos engajados do outrora, reconhece esta mesma atitude desviante como fundante para sua redenção. Enfim, Lowy escreve: "A redenção, o Juízo Final da teses III, é então uma apocatástase no sentido de que cada vítima do passado, cada tentativa de emancipação, por mais humilde e 'pequena`que seja, será salva do esquecimento e 'citada no ordem do dia', ou seja, reconhecida, honrada, rememorada." (LOWY, 2005, 55). Talvez, este olhar melancólico e o tema sobre a "redenção às avessas" em curso, segundo a "reviravolta alegórica", da qual tratamos aqui, possam ser vistos como marco do viés político de nossa leitura. 
A política da redenção, nas suas interfaces estética e teológica, prenunciadas na intenção melancólica que anunciamos, será assunto colocado por Benjamin num corte propositivo sobre a elucubração do modo especulativo com que esta intencionalidade recolhe seus "objetos últimos":

É esta a essência da contemplação absorta do melancólico: os seus objetos últimos, nos quais ela julgava apropriar-se com mais segurança do rejeitado, transformam-se em alegorias; o nada em que eles se representam é preenchido e depois negado, do mesmo modo que a intenção, por fim, à vista das ossadas, não se mantém fiel a si mesma, mas se refugia, infiel, na ressurreição. (BENJAMIN, 2013, 251).

Neste lugar lembremos o "niilismo revolucionário" surrealista, que dobra ao menos uma página crucial nessa concepção sobre a expressividade alegórica, empregada no movimento e nos seus procedimentos de escrita automática. Mas, antes disso, destacamos que o olhar abismado e o muralismo semântico na operação estético- redentora das alegorias desloca sua forma lacunar para uma oscilação pulsante. Quer dizer, cair no abismo alegórico não significa simplesmente esgotar todas as figurações pelo mutismo e o abandono da noção de libertação final, justo porque coexiste uma atração ressurrecional, a libertação atingida na interrupção do sono que o embalava. É um vagar que, no entanto, anseia chegar ao destino salvador e por este motivo atingir seu objetivo, desviada sua intenção para quebrantar o silêncio de uma natureza mitificada. Por outro lado, nas palavras de Benjamin: "O mal absoluto, que ela [a Natureza] cultivava como abismo perene, existe apenas nela, é exclusivamente alegoria, significa algo diferente daquilo que é." (BENAJMIN, 2013, 251). Neste sentido, os objetos lançados na encenação da queda só podem ser restituídos neste movimento drástico, no "instante de perigo", como Benjamin mesmo escreve na "tese" de número VI, enquanto resultado dessa mesma drasticidade. Por exemplo, quando Benjamin escreve que "articular o passado historicamente não significa conhece-lo 'tal como ele propriamente foi'. Significa apoderar-se de uma lembrança tal como ela lampeja num instante de perigo." (BENJAMIN, $2005,65)$ e a esta altura todos os advérbios para o repentino se aglomeram no tempo de agora (Jetzt-Zeit). Todavia, o "relampejar dessa memória", guiada pela intenção melancólica, salva os fenômenos ao desdobrá-los em sentidos vários que perduram sobre o abismo até cansar suas asas e ser engolido. 
Adversa, a alegoria mostra o definhamento pela impulsão das imagens e seu conteúdo, encontrado no corpo morto, na miséria, na ruína, no retrato fragmentário e no mal, enquanto vultos de um passado em debandada, abertos os porões da memória, extravasada uma série de sentimentos quais a harmonização simbólica tanto se precavia. E redimido seria aquele povo que tomasse, por exemplo, todo o seu passado e as lutas que travaram seus antepassados como suas, e fizesse do presente um momento redentor inescapável e a ser alcançado. O mal, soergue essa expedição porque, na sua discrepância, escapa a palavra intocável quando na sua existência superior (originária), estava restringida a um reino divino, encerrada numa linguagem que nos era inacessível. O mal que viria à tona por uma intervenção do juízo que duvida, quando tudo para o bem é plenamente vislumbrado em deus, provoca uma laminação significativa da realidade. O estardalhaço de uma expressão que implode os sentidos, como fazem as alegorias, e que resume toda atmosfera melancólica que configura suas inventivas.

\footnotetext{
O saber do mal não tem, assim, qualquer objeto. O mal não existe no mundo. Surge no homem apenas com a vontade de saber, ou melhor, de julgar. O saber do bem, enquanto saber, é secundário. Resulta da prática. O saber do mal, enquanto saber, é primário. Resulta da contemplação. O saber do bem e do mal é, assim, o oposto de toda saber objetivo. (BENJAMIN, 2013, 252).
}

Saber é exercício de ajuizamento e, enquanto juízo que é, saber condiz àquela subjetividade que está imbuída na emancipação do saber e de si mesma, quando, melancólica, escolhe seus objetos desde a tradição oprimida. Como escreve Benjamin, seus atributos na maldade são os mais producentes para uma configuração subjetiva revolucionária, claro, dito isto após as intermediações linguísticas que o juízo lhe apregoa. A dúvida, que o ser humano porta como algo imanente a situação de ser caído, encarnado como o típico falador da linguagem decaída, representa esse mal porque, quem julga, logo, titubeia sobre o bem inefável e intocado. Segundo Benjamin: "Na sua qualidade de triunfo da subjetividade e irrupção de uma dominação arbitrária das coisas, esse saber é a origem de toda a contemplação alegórica. É no próprio pecado original que emerge a unidade de culpa e significação como abstração, diante da 'árvore do conhecimento'" (BENJAMIN, 2013, 252). Neste caso, maior a largura do tombo, 
maior o raio das especulações que fomenta sua causa de anúncio. O abismo, em última análise, representa essa tensão suspensiva na dialética arguta, que é ritmada no coração deste imaginário alegórico - esta que faz parte dos serões do intriguista e das elucubrações do tirano, como escreve Benjamin (2013). Enquanto os nomes estão crivados na concretude dos objetos, o juízo, para o pensamento de Benjamin (2013), corresponderia aos "elementos linguísticos abstratos" $(2013,252)$ dentro de uma gramática simbólica do barroco. Ou seja, o juízo permanece alinhado a uma abstração notória, especialmente dedicada aos objetos miúdos como ao próprio esmiuçar do registro escrito e seus códices diversos, mas que representa, a princípio, um desvio ao instrumentalismo. A esta altura, o juízo é mais compatível com a pura teoria e sua especulação ordinária, como mácula que agride a plenitude no conhecimento do bem e da perfeição, para liberar a inteligência para uma reintegração com a natureza, do que a inteligência abstracionista. Contudo, sua forma de integração somente poderia ser compreendida por esta contradição. Se antes, aprisionada ao espírito terreno, imaginava a punição como fonte escandalosa de interconexão do mundo terreno com o paraíso, neste patamar agudo em que encontramos a sabedoria, será uma "ilusão do mal que conquista direito de cidade" - nas palavras de Benjamin: "E enquanto no tribunal terreno a vacilante subjetividade do juízo se agarra firmemente a realidade através da punição, no tribunal celeste é a ilusão do mal que conquista direito de cidade." (BENJAMIN, 2013, 252). Seu flagelo terminante demonstra uma integração sui generis, quando sim, realiza esta integração, mas alegoricamente e sugere, portanto, a estruturação da subjetividade barroca numa versão axiomática das noções de bem e mal:

Não é aparência, mas também não é ser pleno, mas o verdadeiro reflexo, no bem, da subjetividade vazia. No mal absoluto, a subjetividade apropria-se do seu real e vê-o como mero reflexo de si mesma em Deus. Na visão do mundo da alegoria a perspectiva subjetiva está, portanto, totalmente integrada na economia do todo. (BENJAMIN, 2013, 252).

Em reciprocidade, o bem e o mal adequam-se à "economia do todo", que vigora no esvaziamento da subjetividade quando refletida no bem enquanto a ressonância de si mesma, e para o pensamento do mal absoluto, transfere-se como reflexo posto em deus. O que torna as alegorias objetos de uma política Mestrando em Filosofia pela Universidade Federal de Ouro Preto. Brasileiro, residente em Juiz de Fora - MG. Email: rodrigorochadeoliveiracod@gmail.com 
da escrita benjaminiana como práxis melancólica de crítica histórica é objeto desta narrativa que integra pela desintegração - o que, apesar do tom pitoresco, reiteramos, funciona nesta descrição que se dá para o conceito de redenção que apontamos. (A concepção de uma divindade não maniqueísta é, principalmente, parte desse substrato alegórico reintegrado). Sobretudo, sua perspectiva nos reserva uma tendência invertida, de troca da vida pela morte. E sua ênfase nos menores objetos, e nos objetos estranhos, que, certamente, são caracteres inconfundíveis para uma historiografia da modernidade permanecerão como invariante. Este olhar volta-se para o precário e o extinto na realização de uma subjetividade integrada, que olha do plano terreno em que se encontra ao aparecer voltado para o paraíso iminente, e faz da composição da sua escrita o exercício desse ruminar.

\section{REFERÊNCIAS}

BENJAMIN, Walter, Linguagem, tradução, literatura (filosofia, teoria e crítica). Edição e Tradução de João Barrento. 1ª ed. Belo Horizonte: Autêntica, 2018. (Filô/Benjamin).

Magia e técnica, arte e política: ensaios sobre literatura e história da cultura. Trad. de Sérgio Paulo Rouanet. - 7. ed. - São Paulo: Brasiliense, 1994.

. Origem do drama trágico alemão. Edição e Tradução de João Barrento. $2^{\mathrm{a}}$ ed. Belo Horizonte: Autêntica, 2013.

Walter Benjamin: aviso de incêndio: uma leitura das teses "Sobre o conceito de história". In _ : Teses sobre o conceito de História. Tradução de Jeanne Marie Gagnebin e Marcos Lutz Muller. São Paulo: Boitempo, 2005.

GAGNEBIN, Jeanne Marie. Do conceito de Darstellung em Walter Benjamin ou Verdade e Beleza. In_: KRITERION, Belo Horizonte, n 112, p. 183-190, dez/2005. 
História e Narração em Walter Benjamin. São Paulo: Perspectiva, 2013.

Walter Benjamin: os cacos da história. Tradução de Sônia Salzstein. São Paulo: $n-1$ edições, 2018.

LAVELLE, Patrícia, A árvore e o juízo: As raízes criticistas da filosofia da linguagem de W. Benjamin. In_: Arte filosofia, Ouro Preto, $n^{\circ}$ 6, p. 95-105, abr. 2009.

LOWY, Michael. Walter Benjamin: aviso de incêndio: uma leitura das teses "Sobre o conceito de história". Tradução de Wanda Nogueira Caldeira Brant [tradução das teses], Jeanne Marie Gagnebin e Marcos Lutz Muller. São Paulo: Boitempo, 2005.

RANGEL, Marcelo de Mello, Melancolia e história em Walter Benjamin. In Ensaios Filosóficos, Rio de Janeiro, Volume XIV- Dezembro/2016.

TRAVERSO, Enzo, Melancolia de Esquerda: Marxismo, História e Memória, Trad. André Bezamat. Belo Horizonte: Ayiné, 2018.

WILLIAMS, Raymond, A produção social da escrita, Trad. André Glaser. São Paulo: Editora Unesp, 2014.

Unesp, 2011.

Cultura e materialismo, Trad. André Glaser. São Paulo: Editora da

Política do modernismo: contra os novos conformistas, Trad. André Glaser. São Paulo: Editora Unesp, 2011.

WITTE, Bernd. Walter Benjamin: uma biografia. Tradução de Romero Freitas. $1^{\underline{a}}$ ed. Belo Horizonte: Autêntica, 2017. 